OPEN

SUBJECT AREAS:

ENVIRONMENTAL

MONITORING

ENVIRONMENTAL SCIENCES

Received

9 December 2013

Accepted

1 August 2014

Published

22 August 2014

Correspondence and requests for materials should be addressed to C.N. (carlos.delnor@ gmail.com)

\section{Carbon dioxide emissions from estuaries of northern and northeastern Brazil}

\author{
Carlos Noriega \& Moacyr Araujo
}

Department of Oceanography- DOCEAN, Center for Risk Analysis and Environmental Modeling - CEERMA, Federal University of Pernambuco - UFPE, Av. Arquitetura, s/n, Cidade Universitária, 50740-550, Recife-PE, Brazil.

The carbon dioxide flux through the air-water interface of coastal estuarine systems must be quantified to understand the regional balance of carbon and its transport through adjacent coastal regions. We estimated and calculated the emissions of carbon dioxide $\left(\mathrm{FCO}_{2}\right)$ and the partial pressure of $\mathrm{CO}_{2}\left(p \mathrm{CO}_{2}\right)$ values in 28 estuarine environments at a variety of spatial scales in the northern and northeastern regions of Brazil. The results showed a mean $\mathrm{FCO}_{2}$ (water to air) of $55 \pm 45 \mathrm{mmol} \cdot \mathrm{m}^{-2} \cdot \mathrm{d}^{-1}$. Additionally, a negative correlation between dissolved oxygen saturation and $\mathrm{pCO}_{2}$ was observed, indicating a control by biological processes and especially by organic matter degradation. This leads to increased dissolved $\mathrm{CO}_{2}$ concentration in estuarine waters which results in a $\mathrm{pCO}_{2}$ that reached $8,638 \mu \mathrm{atm}$. Our study suggests that northern and northeastern Brazilian estuaries act as sources of atmospheric $\mathrm{CO}_{2}$. The range of $\mathrm{pCO}_{2}$ observed were similar to those found in inner estuaries in other places around the world, with the exception of a few semi-arid estuaries (Köppen climate classification - BSh) in which record low levels of $p \mathrm{CO}_{2}$ have been detected.

R ivers and estuaries play an important role in the transport and transformation of carbon from the continent to the adjacent coastal zone and typically act as sources of $\mathrm{CO}_{2}$ to the atmosphere ${ }^{1-4}$. Estuaries are often strongly influenced by human activities. Attention has been focused on estuaries as potentially important sites of organic matter cycling in the coastal zones in recent decades. Estuaries are regarded as sources of $\mathrm{CO}_{2}$ to the atmosphere because of their elevated loads of detrital organic matter that drives intense respiration ${ }^{5}$.

The exchange of $\mathrm{CO}_{2}$ between inner estuaries and the atmosphere has been recently evaluated using data from 106 systems $^{6}$. The estimated global emissions of $0.26 \mathrm{Pg} \mathrm{C} \mathrm{year}^{-1}$ from these systems is lower than previous estimates, which have been in the range of 0.27 to $0.60 \mathrm{PgC} \mathrm{year}^{-11,2,7-9}$. However, all recent studies have reported higher values than those first reported $\left(0.1 \mathrm{Pg} \mathrm{C}_{\text {year }}^{-1}\right)^{10}$.

Very little is known about the seasonal and interannual variability of the $\mathrm{CO}_{2}$ flux at the air-water interface in rivers and estuaries of Brazil, and particularly in the northeastern region of the country. Recently, two studies in tropical estuaries in northeastern Brazil reported values of 30 and $35.6 \mathrm{mmol} \mathrm{m}^{-2} \mathrm{~d}^{-111,12}$.

The climatic diversity found in the basins of the Atlantic coast of Brazil is a function of their position in relation to atmospheric circulation systems such as the South Atlantic tropical cyclone and the polar anticyclone. The basins of the Atlantic coast present a range of climates from the warm tropical climate of the south to humid and semi-humid climates as well as semi-arid regions in the north ${ }^{13}$.

To quantify $\mathrm{CO}_{2}$ emissions from the Brazilian estuaries, water samples were collected monthly from 6 estuaries (12 months - 72 observations). Additionally, we estimated the amount of carbon emissions from rivers and estuaries using measurements of salinity, temperature, alkalinity and $\mathrm{pH}$ at low tide from 22 systems (78 observations) along the northern and northeastern Brazilian coast during the wet and dry periods (Fig. 1).

The objectives of this study are to characterize and quantify the variability of $\mathrm{CO}_{2}$ emissions and the variables associated with the carbonate system in the tropical systems located in northern and northeastern Brazil. The characterization of these emissions is associated with population density, climate type and estuarine gradient. Finally, we assess the contribution of excess $\mathrm{CO}_{2}$ input by rivers to the total $\mathrm{CO}_{2}$ emission to the atmosphere from the estuaries through correlation with others species of the carbonate system, as well as oxygen and nutrients.

\section{Results}

Climatology and fluvial discharge. The mean annual water discharge from the Brazilian estuaries studied here varies from 1.0 to $5,946 \mathrm{~m}^{3} \mathrm{~s}^{-1}$, contributing with $8,740 \mathrm{~m}^{3} \mathrm{~s}^{-1}\left(276 \mathrm{~km}^{3}\right.$ year $\left.{ }^{-1}\right)$ to the Atlantic Ocean (Table 1). The observed pluviometric precipitation and evaporation were not significantly different from their historical averages (1982-2012) (t-test; $\alpha=0.05)$. The relationship between river discharge and $p \mathrm{CO}_{2}$ was explored for each 


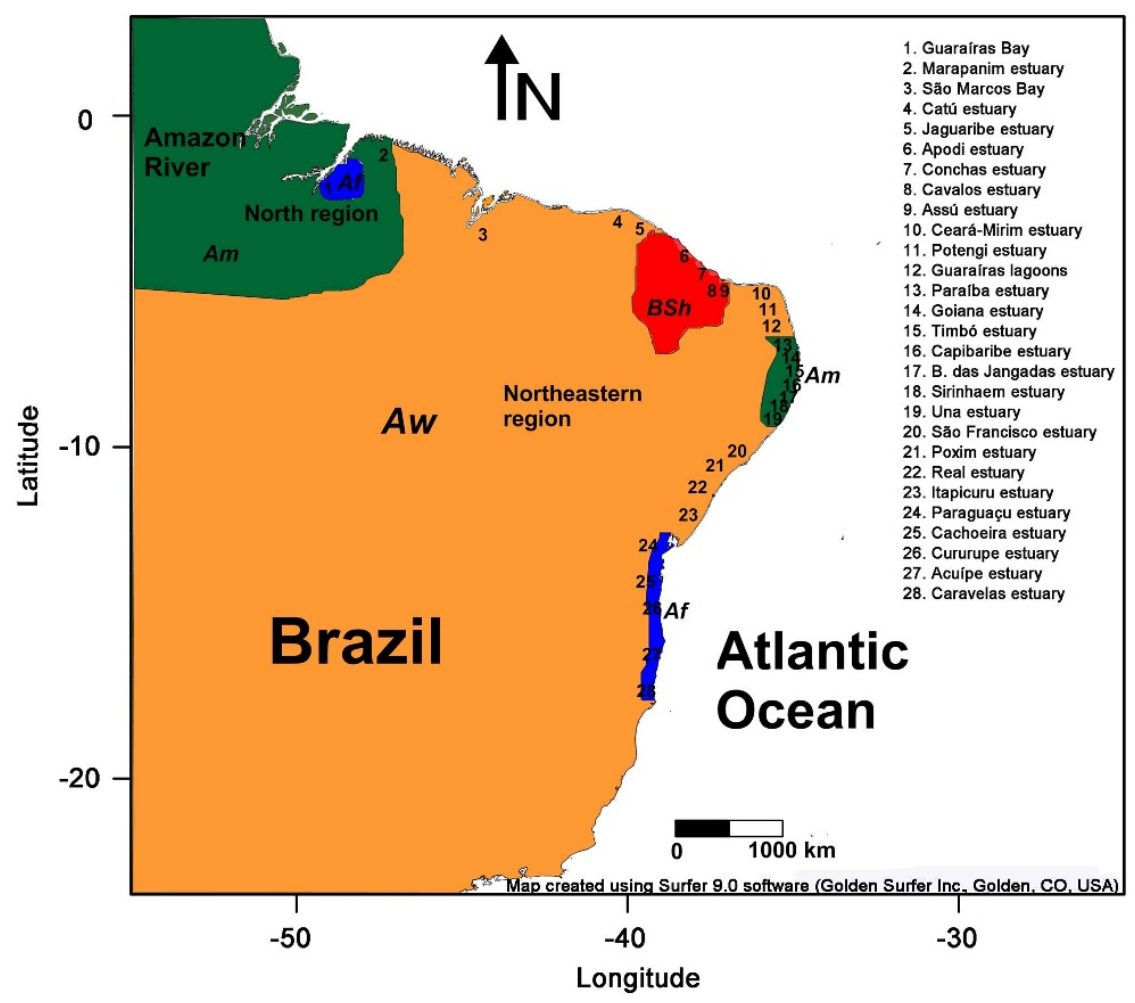

Figure 1 The Köppen climate classification ${ }^{29}$ of the Brazilian estuaries considered in this study: Am (tropical wet climate), Af (tropical rainforest climate), $A w$ (tropical wet and dry or savanna climate) and BSh (semi-arid climate). Map generated with Surfer $9.0^{\circledR}$ software.

system (18 systems; Table 2 ). The river discharge was positively correlated with $p \mathrm{CO}_{2}$ values in $44.4 \%$ of the systems. However, the systems that showed a positive correlation in Table 2 showed no association with population density or a specific climate type.

Distribution of physical and chemical parameters. The salinity varied widely along the coast (0.2-46 units), indicating a strong interaction with precipitation and evaporation as well as soil characteristics of the drainage basins (Table 1). Low salinities were found in the upper estuaries and in Guajará Bay (in the northern region). High salinities (38.8-46 units) were observed in the latitudinal band between $-4.8^{\circ}$ and $-5.1^{\circ}$ (the Apodi, Conchas, Cavalos and Assu Estuaries). The water balance was negative in these estuaries because evaporation was 8.5 fold higher than precipitation. The Spearman correlation coefficient values indicated that salinity was positively correlated $(\alpha=0.05)$ with temperature, $\mathrm{TA}, \mathrm{DO} \%$ and $\mathrm{pH}$ and negatively correlated with $p \mathrm{CO}_{2}$ and $\mathrm{CO}_{2}$ fluxes $\left(\mathrm{FCO}_{2}\right)$.

Water temperatures along the coast ranged from 24.6 to $29.5^{\circ} \mathrm{C}$. The estuaries of the northern region (Guajará Bay, Marapanim and São Marcos Bay) had temperatures that were $3.6^{\circ} \mathrm{C}$ higher (averages: $28.9-25.3^{\circ} \mathrm{C}$ ) than the estuaries located at the other extreme of the latitudinal band (Cururupe, Acuípe and Caravelas).

The $\mathrm{pH}$ values in the monitored estuaries varied widely (from 6.60 to 8.20 ) (Table S1; Supplementary Material). Low values $(<7.0)$ were observed in the northern (Guajará Bay) and southern (the Real, Cururupe and Acuípe Estuaries) regions, whereas high values $(>7.8)$ were observed in the northeastern estuaries (Catu, Jaguaribe, Apodi, Conchas and Cavalos) located between latitude $-3.9^{\circ}$ and $-5.1^{\circ}$. The correlation between $\mathrm{pH}$ values and $\mathrm{DO} \%$ values was low $\left(r^{2}=0.49 ; p<0.0001\right)$ (Fig. 2a).

The estuarine systems had a mean Dissolved Oxygen (DO) saturation of $67 \pm 18 \%$ and a mean DO concentration of $146 \pm$ $60 \mu \mathrm{mol} \mathrm{L}^{-1}$ (Table S1; Supplementary Material). Values lower than $156 \mu \mathrm{mol} \mathrm{L} \mathrm{L}^{-1}$ are below the limit recommended in the Brazilian legislation ${ }^{14}$. In this study, $50 \%$ of the samples tested had DO concentrations below this limit $\left(156 \mu \mathrm{mol} \mathrm{L} \mathrm{L}^{-1}\right)$. A regression analysis demonstrated a strong negative exponential correlation between $\mathrm{DO} \%$ and $p \mathrm{CO}_{2}\left(r^{2}=0.92 ; p<0.0001\right)$ (Fig. 2b).

TA and DIC in the Brazilian monitored estuaries (Table 1 and Supplementary Material S1) varied widely between 131 and $2,800 \mu \mathrm{M}$ for TA and between 241 and 2,527 $\mu \mathrm{M}$ for DIC. High DIC concentrations $(>2,000 \mu \mathrm{M})$ were observed in the northeastern estuaries (Apodi, Conchas, Cavalos, Assu, Potengi and Caravelas), whereas lower values $(<400 \mu \mathrm{M})$ were observed in the northern and southern estuaries (Guajará Bay and Cururupe). TA and DIC were strongly correlated with salinity and $\mathrm{pH}$ (Spearman's correlation; $r=$ $0.7 ; \alpha=0.05 ; p<0.0001)$.

$p \mathrm{CO}_{2}$ and $\mathrm{CO}_{2}$ emissions $\left(\mathrm{FCO}_{2}\right)$. The $p \mathrm{CO}_{2}$ values (Table 1) varied widely between 162 and $8,638 \mu$ atm in northern and northeastern estuaries. The $p \mathrm{CO}_{2}$ values of estuaries that receive low water discharges $\left(<50 \mathrm{~m}^{3} \mathrm{~s}^{-1}\right)$ were not significantly different from those of estuaries that receive high water discharges $\left(>50 \mathrm{~m}^{3} \mathrm{~s}^{-1}\right)(\alpha=$ $0.05 ; p<0.7)$. A Spearman correlation analysis showed a strong negative correlation $(\alpha=0.05)$ between $p \mathrm{CO}_{2}$ and salinity, $\mathrm{DO} \%$ and $\mathrm{pH}$. The $\mathrm{pCO}_{2}$ in the water was significantly different in the dry and rainy seasons $(\alpha=0.05 ; p<0.01)$. Monthly mean $p \mathrm{CO}_{2}$ in the rainy season was 1.5 -fold higher than in the dry season. According to the results of Kruskal-Wallis tests $(\alpha=0.05 ; p<0.001)$, the estuaries laying in different climate types ( $A f, A m, A w$ and $B S h)$ had significantly different $p \mathrm{CO}_{2}$ values. $p \mathrm{CO}_{2}$ values were 2 to 3.3fold higher in estuarine systems located in the $A f, A m$ and $A w$ climate zones than those of the system located in the BSh climate zone (Fig. 3). The Kruskal-Wallis test also revealed significant differences $(\alpha=0.05 ; p<0.01)$ in the $p \mathrm{CO}_{2}$ values of the different estuary types (tidal fresh/upper, inner, middle and lower estuaries). The $\mathrm{pCO}_{2}$ values in the lower systems were 1.5-2.6-fold lower than those in the tidal fresh/upper, inner and middle estuaries (Fig. 3). 


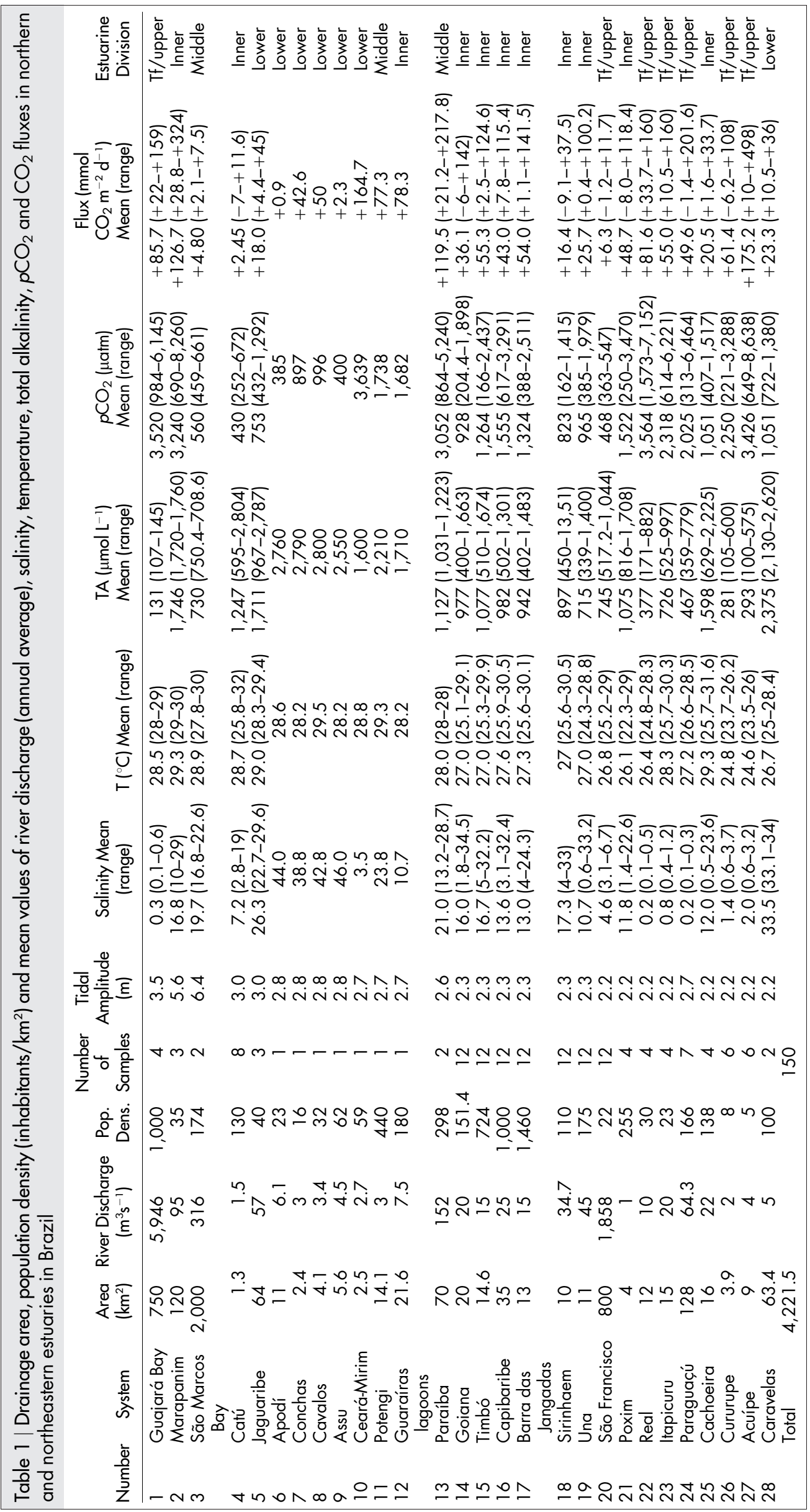


The $\mathrm{FCO}_{2}$ of the monitored Brazilian estuaries ranged between 0.9 and $175.2 \mathrm{mmol} \mathrm{m}^{-2} \mathrm{~d}^{-1}$ (Table 1; Fig. 4) with a mean rate of $55 \pm$ $45 \mathrm{mmol} \mathrm{m}{ }^{-2} \mathrm{~d}^{-1} \cdot \mathrm{CO}_{2}$ emissions significantly differed $(\alpha=0.05 ; p$ $<0.01$ ) seasonally, with monthly rates 1.8 -fold higher during the rainy season when compared with the dry season (Fig. S1; Supplementary Material). The Kruskal-Wallis tests $(\alpha=0.05 ; p<$ $0.01)$ for the climate types ( $A f, A m, A w$ and $B S h)$ demonstrated significant differences in the $\mathrm{CO}_{2}$ fluxes. $\mathrm{CO}_{2}$ emissions in the estuaries characterized by $A f, A m$ and $A w$ climates were 2.2-2.8-fold higher than those in the system within the BSh climate (Fig. 3). The Kruskal-Wallis test also demonstrated significant differences in $\mathrm{CO}_{2}$ emissions $(\alpha=0.05 ; p<0.001)$ according to estuarine type (inner, middle or lower), where the lower systems showed 2-3.6-fold lower rates (Fig. 3).

$\mathrm{CO}_{2}$ emissions from $4,222 \mathrm{~km}^{2}$ of estuarine area in the northern Brazilian were estimated to be $1.01 \mathrm{Tg} \mathrm{C}^{-1}$.

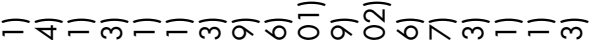
O०㇒O 000000000000000

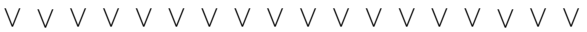

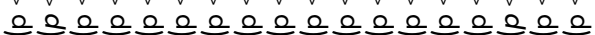

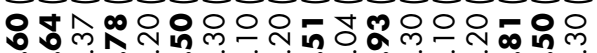

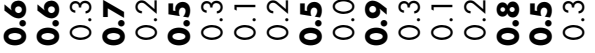

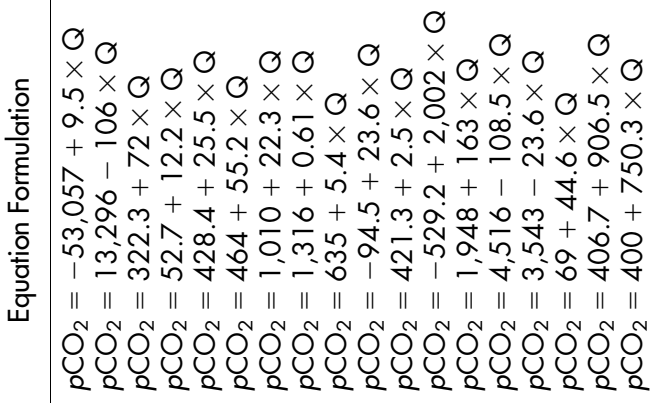

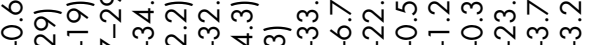

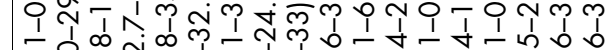

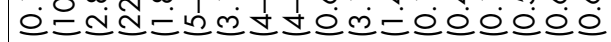

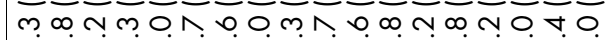
ơ

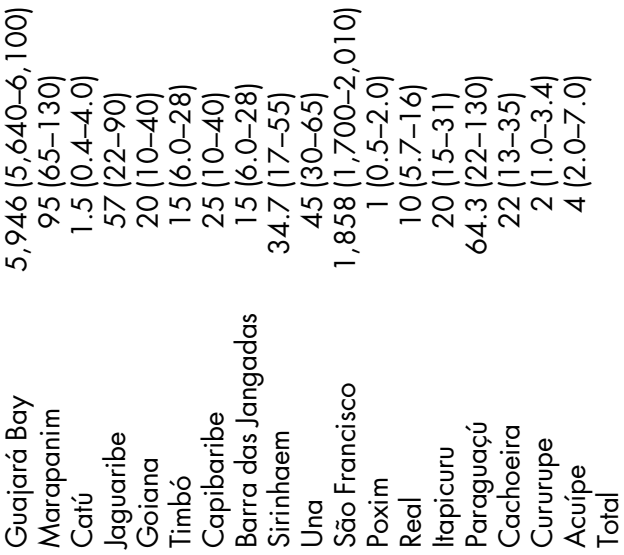

\section{Discussion}

The processes that partition dissolved $\mathrm{CO}_{2}, p \mathrm{CO}_{2}$ and DIC in estuarine environments are complex and are influenced by a combination of factors and natural processes, such as the types of rock and soil in the hydrographic basin, the water-atmosphere interactions and the oxidation/reduction reactions of anthropogenic inputs ${ }^{4}$. However, most of these processes are controlled primarily by the $\mathrm{pH}$. The results of this study indicate that the typical tropical coastal systems in the northern and northeastern regions of Brazil reflect significant heterotrophy in terms of the $\mathrm{CO}_{2}$ fluxes (average: $55 \pm$ $45 \mathrm{mmol} \mathrm{m}{ }^{-2} \mathrm{~d}^{-1}$ ) and the high levels of $p \mathrm{CO}_{2}$ observed (average: $1,564 \mu \mathrm{atm})$. Analyses were conducted to determine whether the rock and soil types influence the water $\mathrm{CO}_{2}$ content. No correlation between fluvial discharge and $p \mathrm{CO}_{2}$ was observed, suggesting that the transport processes via fluvial runoff are not the primary factors responsible for the high concentrations of dissolved $\mathrm{CO}_{2}$ found in the Brazilian estuaries monitored in this study. Other studies have shown that the lack of correlation between these two variables is characteristic of basins that are located in populous industrialized areas ${ }^{15}$. For example, in the Zenne River (an urban river in Brussels, Belgium), periods of high fluvial discharge have not been found to be correlated with high $p \mathrm{CO}_{2}$ values $^{16}$. PCA analysis results (Fig. 5) showed a strong positive correlation between rainfall and $p \mathrm{CO}_{2}$ in Guajará Bay (in the northern region). Guajará Bay had the highest river discharge of the systems studied $\left(5,946 \mathrm{~m}^{3} \mathrm{~s}^{-1}\right)$ as a result of the high runoff of the Pará River. In the northern region (systems 1 to 3; Fig. 1 and Fig. 3 ), tropical climate ( $A f$ and $A m$ types) predominates precipitation in this region is 2.3 -fold higher than in the northeastern region (systems 4 to 28; Fig. 4). However, the evaporation in the northeastern region is 2 -fold higher than that in the northern region. The BSh climate (4 systems) strongly influenced this result. The climate in this region is semi-arid (BSh type), and the estuaries are surrounded by shrimp farms, salt ponds and agricultural areas. The mean annual freshwater discharge in the region was $4.3 \mathrm{~m}^{3} \mathrm{~s}^{-1}$, and the rate of evaporation was 8.5 -fold higher than the precipitation measured during this study. The difference between the mean temperatures of the northern and northeastern regions was $1.3^{\circ} \mathrm{C}$. The reported mean temperatures of the water masses adjacent to the coasts of the northern and northeastern regions of Brazil were $27.6^{\circ} \mathrm{C}$ and $27.2^{\circ} \mathrm{C}^{17,18}$, respectively. We obtained similar results for the estuaries of the northern and northeastern regions $\left(28.5^{\circ} \mathrm{C}-\right.$ $27.6^{\circ} \mathrm{C}$; Table 1$)$.

A strong negative correlation between $\mathrm{DO} \%$ and $p \mathrm{CO}_{2}$ (Fig. 2b) was detected, suggesting that intense organic matter decomposition in the estuaries, either in the water column or the sediment, results in a decrease in $\mathrm{pH}$ (Fig. 2a) and enhanced $p \mathrm{CO}_{2}$ values. Other processes such as direct groundwater discharge, biogeochemical reactivity at seepage faces or benthic organic matter processing could also influence the observed surface water composition in these estu- 

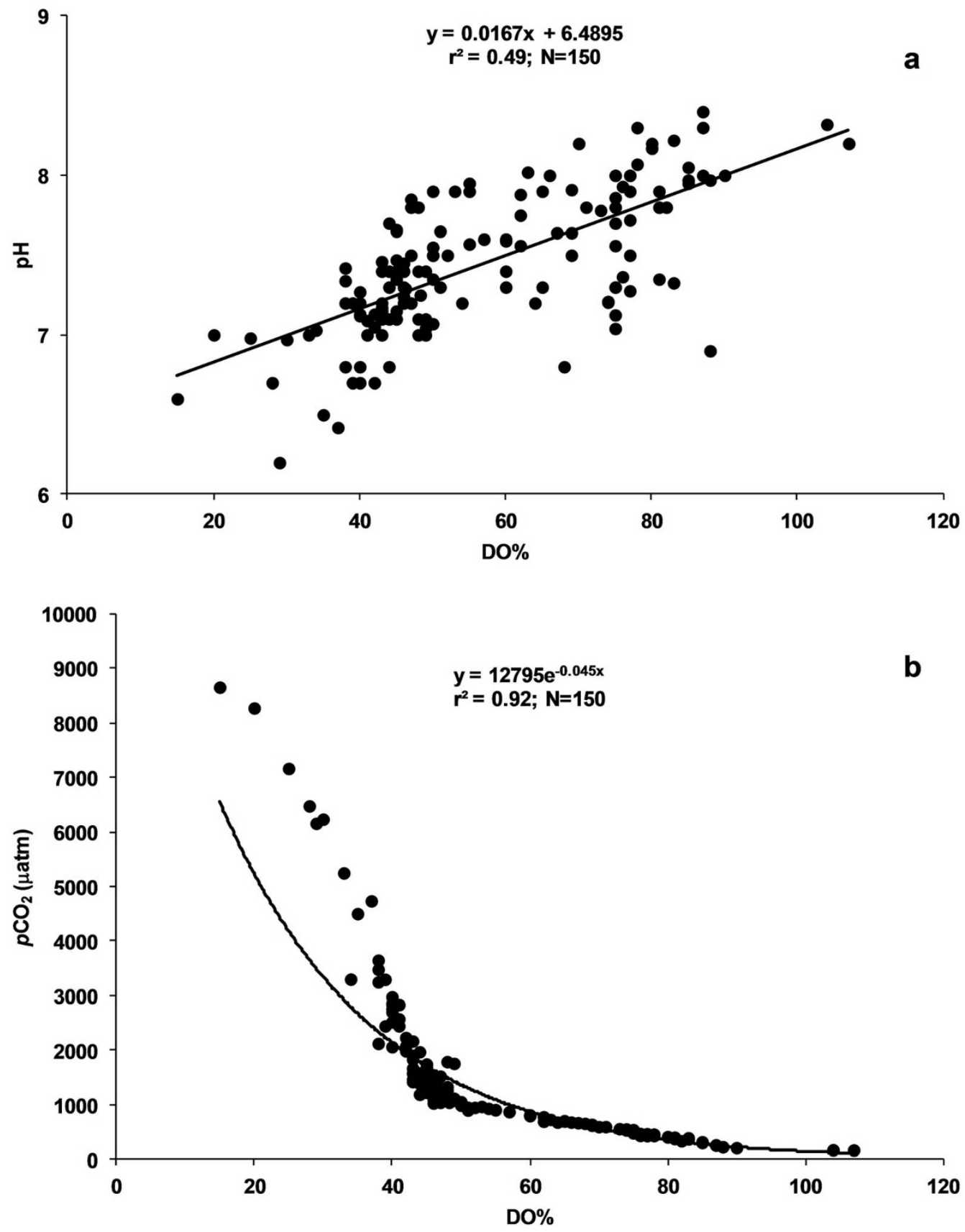

Figure $2 \mid$ The relationship between $\mathrm{DO}(\%)$ and $\mathrm{pH}(\mathrm{a})$ and $\mathrm{pCO}_{2}(\mathrm{~b})$.

aries $^{19-21}$. Additionally, the AOU (Table S1; Supplementary Material) was positively correlated with the excess $\mathrm{CO}_{2}\left(r^{2}=0.51 ; p<0.0001\right)$, which indicates that the organic load that enters the systems has a significant impact on the microbial processes that are associated with the carbon and nitrogen cycles. The DIP measurements were strongly correlated with $p \mathrm{CO}_{2}$ values in systems where the population density was $>100$ inhabitants $/ \mathrm{km}^{2}\left(r^{2}=0.51 ; p<0.002\right)$. This nutrient enrichment can lead to the excessive production of algal biomass and consequently to eutrophication. Under high $\mathrm{CO}_{2(\mathrm{aq})}$ values, which result from bacterial respiration, carbonic acid is produced and the water $\mathrm{pH}$ decreases ${ }^{15}$. If the characteristics of a water body are such that the $\mathrm{CO}_{2}$ concentration in the aqueous media is close to equilibrium with the atmospheric $\mathrm{CO}_{2}$ levels, strong correlation among $\mathrm{TA}, p \mathrm{CO}_{2}$ and $\mathrm{pH}$ can be expected. However, the complex set of processes that lead to the production or consumption of $\mathrm{CO}_{2(\mathrm{aq})}$ and the production or removal of carbonic acid $\left(\mathrm{HCO}_{3}{ }^{-}\right)$ prevent the establishment of a correlation among $\mathrm{TA}, \mathrm{pH}$ and $p \mathrm{CO}_{2}{ }^{4,15}$. TA exhibited a strong correlation with $\mathrm{pH}$ but not with $p \mathrm{CO}_{2}$. High TA values (average: $1,298 \mu \mathrm{mol} \mathrm{L}^{-1}$ ) may therefore be associated with the high values of $\mathrm{HCO}_{3}{ }^{-}$that are found mainly in the northeastern systems, which represent $90 \%$ of the total DIC; $\mathrm{CO}_{3}{ }^{2-}$ represents $6 \%$ of the total DIC, and the remaining $4 \%$ is associated with $\mathrm{CO}_{2(\mathrm{aq})}$. These values are consistent with those recorded for highly polluted systems, including tropical rivers, such as the Capibaribe and Tietê Rivers in Brazil ${ }^{4,22}$, and temperate systems, namely, the Scheldt estuary and its tributaries Zenne and Dijle (Belgium and the Netherlands) ${ }^{16}$.

DIC concentrations in the Brazilian estuaries (average: 1,229 $\mu \mathrm{mol} \mathrm{L}{ }^{-1}$ ) were higher than those reported for tropical rivers (average: $\left.695 \mu \mathrm{mol} \mathrm{L}^{-1}\right)^{23}$ and lower than those reported for Indian estuaries (average: $\left.1,777 \mu \mathrm{mol} \mathrm{L})^{-1}\right)^{24}$.

In the inner and upper estuaries, the impoverishment in oxygen due to organic matter remineralization is accompanied by an increase in DIC, TA and $p \mathrm{CO}_{2}$ and a decrease in $\mathrm{pH}$. TA concentra- 

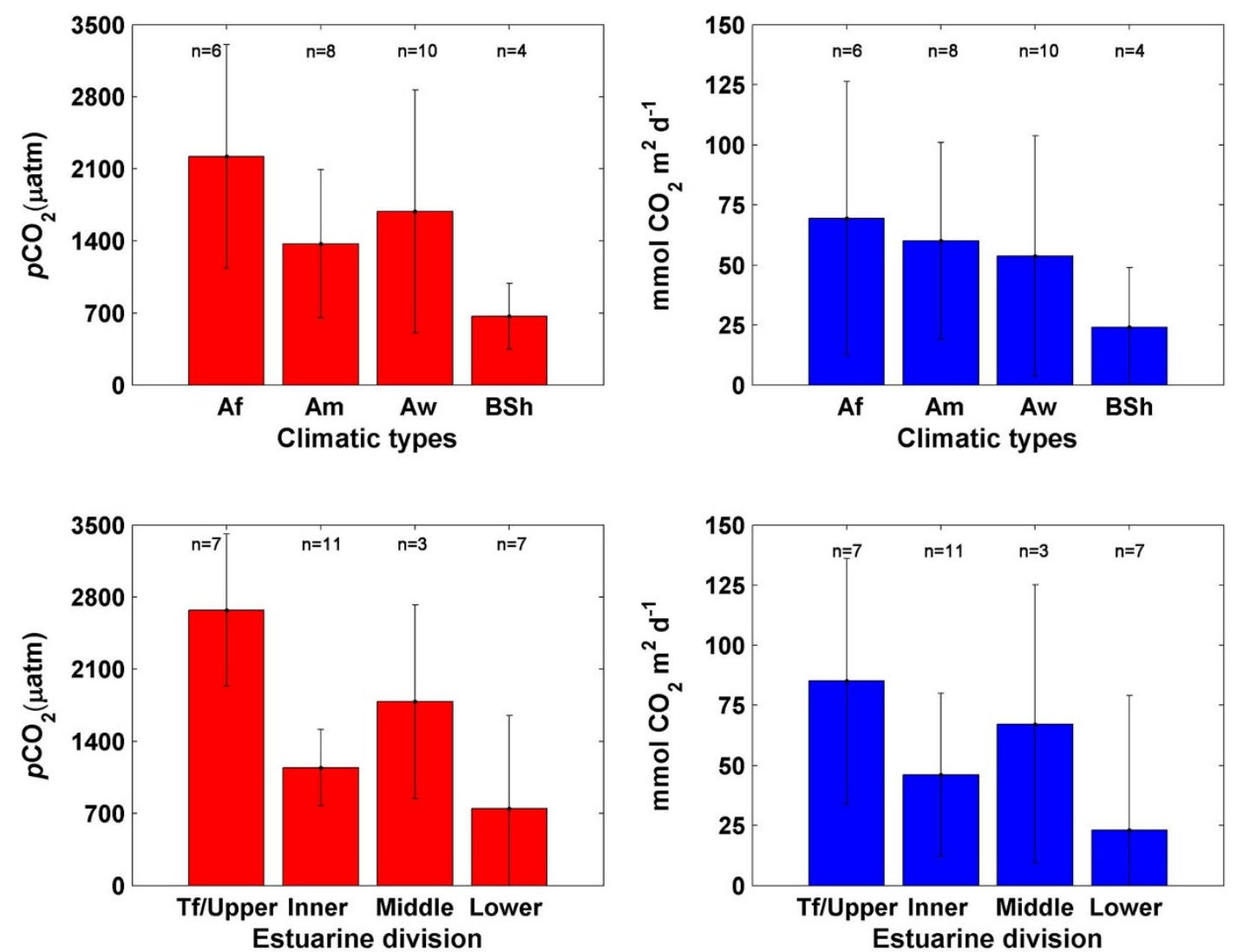

Figure $3 \mid p \mathrm{CO}_{2}$ and $\mathrm{FCO}_{2}$ (averages values) according to climatic type and estuary type for the northeastern Brazilian estuaries. $\mathrm{n}$ indicates the number of samples.

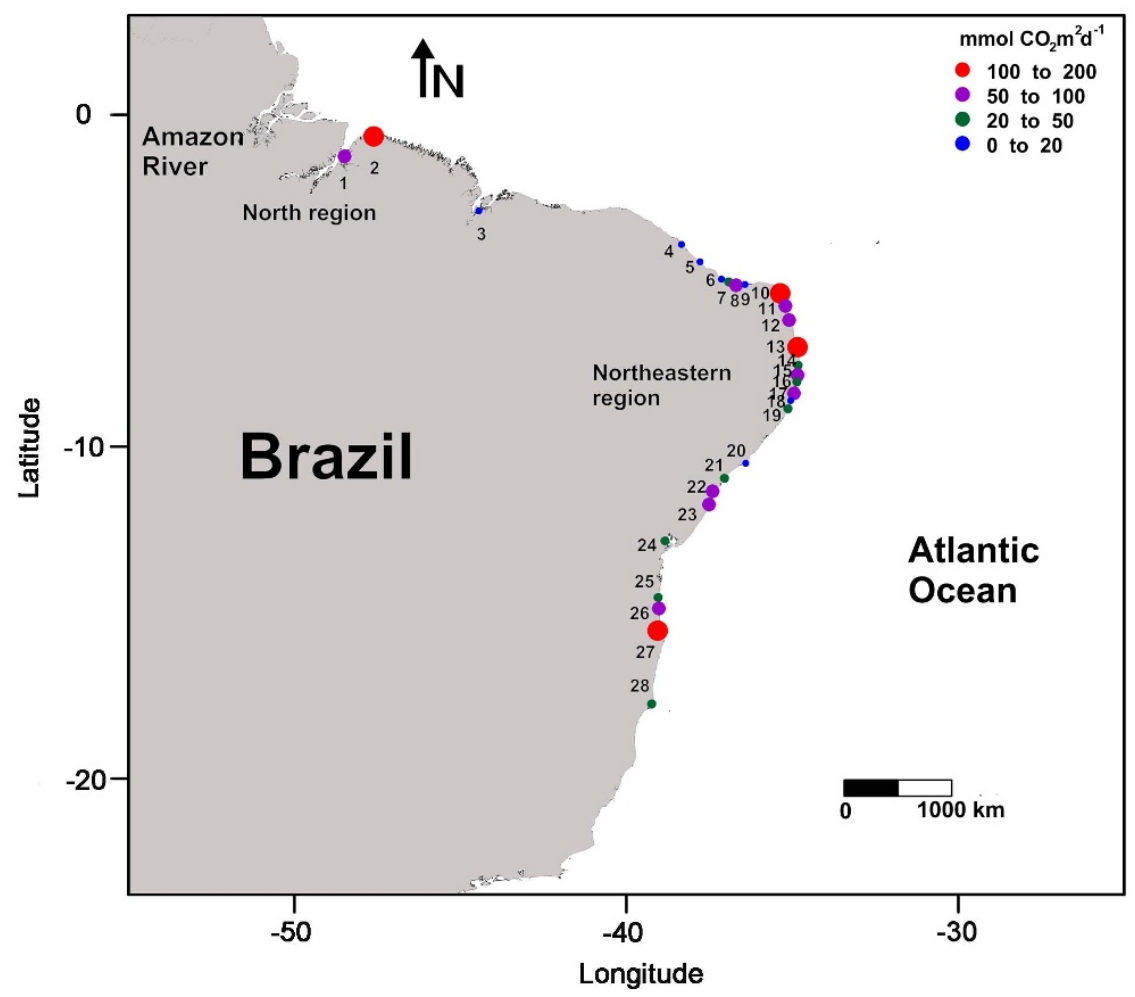

Figure $4 \mid \mathrm{FCO}_{2}$ levels of the northeastern Brazilian estuaries. The numbers represent the estuaries shown in Fig. 1 (figure generated with Surfer $9.0{ }^{\circledR}$ software). 
tions may have also been affected by the incorporation of fulvic and humic acids originated from the mangrove areas or urban sewage ${ }^{11}$, contributing to the high values of TA as noted above.

The average $p \mathrm{CO}_{2}$ in the Brazilian estuaries varied widely, reaching levels up to $8,638 \mu \mathrm{atm}$. The $p \mathrm{CO}_{2}$ levels observed in the Brazilian estuaries are within the reported range for other estuaries around the world. A recent study estimated that on average, upper estuaries around the world have a $p \mathrm{CO}_{2}$ of 3,033 $\pm 1,078 \mu \mathrm{atm}^{6}$. This value is similar to that observed in the present study (average: 2,674 $\mu \mathrm{atm}$ ) for the tidal fresh and upper estuaries (Fig. 3). Our $p \mathrm{CO}_{2}$ values for the middle and lower estuaries (average: 1,783 and $747 \mu \mathrm{atm}$, respectively) were also similar to those reported for other estuaries around the world $(2,277 \pm 626$ and $692 \pm 178 \mu \mathrm{atm}$, respectively) ${ }^{6}$ (Fig. 3). Similar values to those presented here were reported by recent studies for tropical estuaries in the northeastern region of Brazil $(4,700 \pm 2,420$ and 2,200 $\pm 360 \mu \mathrm{atm}$, respectively) ${ }^{11,12}$. The $p \mathrm{CO}_{2}$ supersaturation found in the upper estuaries is not unusual, as estuaries are generally highly heterotrophic ecosystems where the organic carbon carried by rivers is partially remineralized. The spatial $p \mathrm{CO}_{2}$ patterns of the Brazilian estuaries exhibited trends similar to those observed for other estuaries around the world.

The average $\mathrm{FCO}_{2}$ from the Brazilian estuaries is $54.4 \pm 45 \mathrm{mmol}$ $\mathrm{CO}_{2} \mathrm{~m}^{-2} \mathrm{~d}^{-1}$. This value is 2 -fold higher than that reported for Indian estuaries $\left(27 \mathrm{mmol} \mathrm{CO} \mathrm{m}^{-2} \mathrm{~d}^{-1}\right)^{24}$ and 0.73 -fold higher than that presented for tidal systems and small deltas $\left(74 \pm 55 \mathrm{mmol} \mathrm{CO}_{2} \mathrm{~m}^{-2}\right.$ $\left.\mathrm{d}^{-1}\right)^{2}$. A recent study using global-scale segmentation found that the average $\mathrm{CO}_{2}$ emission rate from small deltas and tidal systems was $16.5 \mathrm{~mol} \mathrm{~m}^{-2} \mathrm{y}^{-1}\left(45 \mathrm{mmol} \mathrm{CO}_{2} \mathrm{~m}^{-2} \mathrm{~d}^{-1}\right)^{25}$. This value is very close to that observed in the present study. Tidal systems and small deltas represent over $90 \%$ of the estuarine systems of the northern and northeastern regions of Brazil.

Another recent study indicated that upper estuaries are strong sources of $\mathrm{CO}_{2}\left(106.8 \mathrm{mmol} \mathrm{CO}_{2} \mathrm{~m}^{-2} \mathrm{~d}^{-1}\right)$, middle estuaries are moderate sources of $\mathrm{CO}_{2}\left(47.9 \mathrm{mmol} \mathrm{CO}_{2} \mathrm{~m}^{-2} \mathrm{~d}^{-1}\right)$ and lower estuaries are weak sources of $\mathrm{CO}_{2}\left(23 \mathrm{mmol} \mathrm{CO}_{2} \mathrm{~m}^{-2} \mathrm{~d}^{-1}\right)$. These values are very similar to those obtained in our study $(85,67.2$ and $23 \mathrm{mmol}$ $\mathrm{CO}_{2} \mathrm{~m}^{-2} \mathrm{~d}^{-1}$, respectively $)^{26}$. According to the Kruskal-Wallis and Dunn tests, the estuarine groups in this study showed significant differences $(p<0.05)$ among the upper, middle and lower types. Tidal fresh and inner estuaries emit $\mathrm{CO}_{2}$ to the atmosphere via heterotrophic ecosystem metabolism ${ }^{9,27}$. However, our data $\left(p \mathrm{CO}_{2}\right.$ values and $\mathrm{CO}_{2}$ fluxes) showed high standard deviation values, which complicates comparisons.

We refer to 6 reports indicating that tropical estuaries $\left(<23.5^{\circ}\right.$ latitude) exhibit an average emission rate of $23.9 \pm 28.5 \mathrm{~mol} \mathrm{CO}_{2}$ $\mathrm{m}^{-2} \mathrm{~d}^{-1}\left(65.4 \mathrm{mmol} \mathrm{CO}_{2} \mathrm{~m}^{-2} \mathrm{~d}^{-1}\right)$, which is very similar to the values obtained in the present study for the climatic types $A f(69.3 \mathrm{mmol}$ $\left.\mathrm{CO}_{2} \mathrm{~m}^{-2} \mathrm{~d}^{-1}\right), A m\left(60 \mathrm{mmol} \mathrm{CO}_{2} \mathrm{~m}^{-2} \mathrm{~d}^{-1}\right)$ and $A w\left(53.7 \mathrm{mmol} \mathrm{CO}_{2}\right.$ $\left.\mathrm{m}^{-2} \mathrm{~d}^{-1}\right)$. According to the Kruskal-Wallis and Dunn tests, the climatic groups showed significant differences $(p<0.05)$, primarily between the $A f$ and $B S h$ types. The spatial $\mathrm{FCO}_{2}$ patterns observed in the northern and northeastern Brazilian estuaries were similar to those observed in tropical regions in other studies, indicating similar

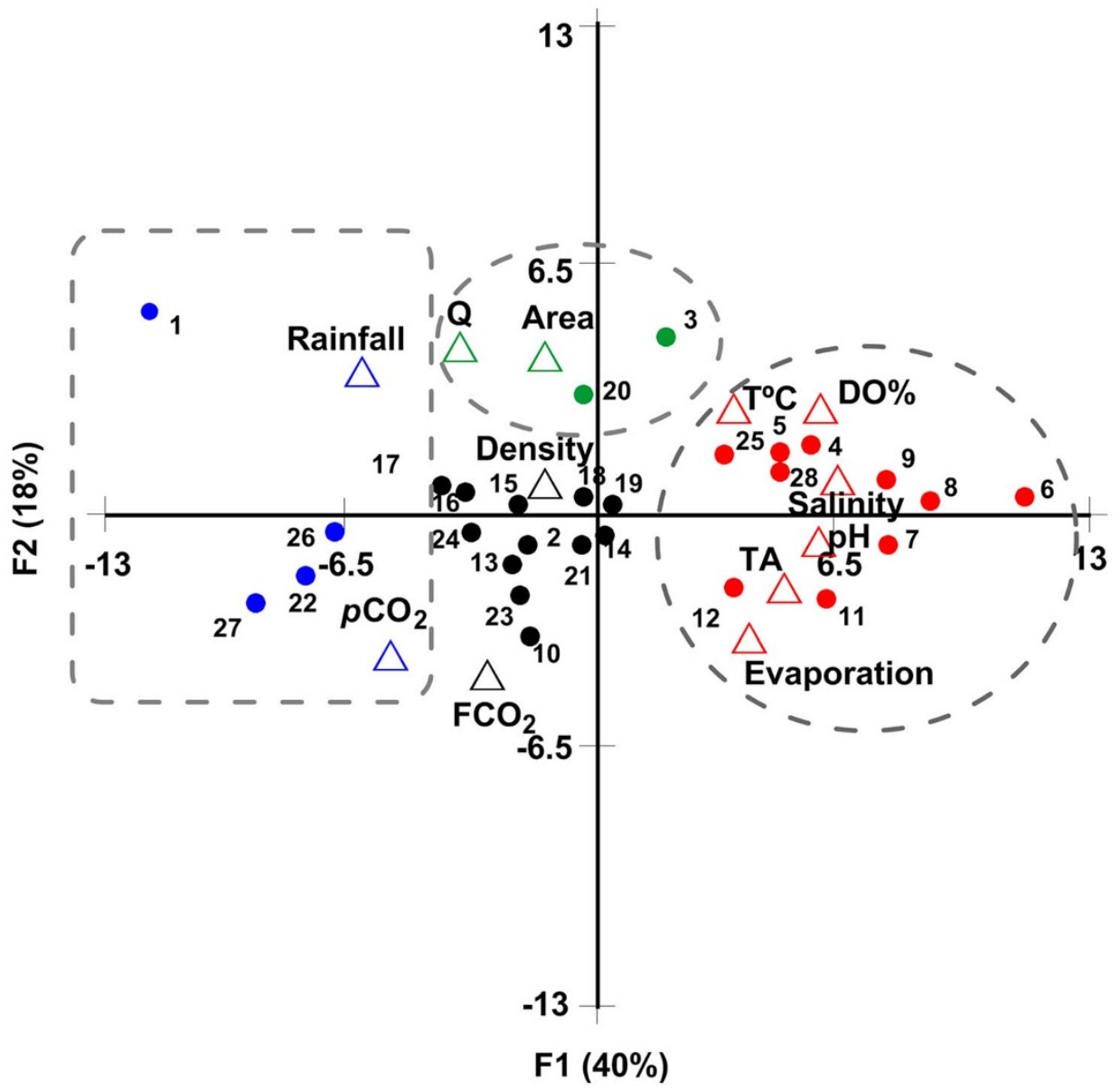

Figure 5 Graphic representations of the results of the principal component analysis (PCA). The four groups correspond to the four associations: rainfall and $p \mathrm{CO}_{2}$ (within the square area); fluvial discharge $(\mathrm{Q})$ and estuarine area (within the smaller oval); evaporation, $\mathrm{DO} \%$, temperature $\left(\mathrm{T}^{\circ} \mathrm{C}\right.$ ), $\mathrm{pH}$, TA and salinity (within the larger oval); and population density and $\mathrm{FCO}_{2}$ (within the central area of the graph). The parameters are indicated by triangles $(\Delta)$, and the estuaries are indicated by filled circles $(\bullet)$. 
hydrological and biological processes, with the exception of the BSh climatic type. As noted above, the semi-arid estuaries in this region are surrounded by shrimp farms, salt ponds and agricultural areas. The rates of $\mathrm{FCO}_{2}$ determined for these systems were similar to those determined for the lower estuaries. As can be noted in Fig. 5, the estuaries in this region exhibited positive correlations among salinity, $\mathrm{TA}, \mathrm{pH}$ and evaporation.

Finally, Brazilian estuaries contribute $1.01 \mathrm{Tg} \mathrm{C} \mathrm{y}^{-1}$ (52\%) less $\mathrm{CO}_{2}$ to the atmosphere than that reported for Indian estuaries $(1.92 \mathrm{Tg} \mathrm{C} y-1)^{24}$. However, the estuarine area of the Brazilian systems presented here is 6.4 times lower than that of Indian estuaries. Small deltas and tidal systems worldwide are estimated to contribute $120 \mathrm{Tg} \mathrm{C} \mathrm{y}^{-1}$ as $\mathrm{CO}_{2}$ to the atmosphere from an area of $360 \times$ $10^{3} \mathrm{~km}^{22}$.

Our study suggests that the estuaries in northern and northeastern Brazil act as sources of $\mathrm{CO}_{2}$ to the atmospheric. The range of $p \mathrm{CO}_{2}$ levels observed was similar to that reported for other inner estuaries, except in the case of a few estuaries of the $B S h$ climatic type for which lowest levels of $p \mathrm{CO}_{2}$ were determined.

The $\mathrm{FCO}_{2}$ observations made in this study contribute to the characterization of humid tropical estuarine systems that previously represented an important geographical information gap.

\section{Methods}

Geographic coverage and types of systems studied. The Brazilian coastal zone spans from latitude $4^{\circ} \mathrm{N}$ to latitude $34^{\circ} \mathrm{S}$. Due to the length of the coast, the interface zone from the continent to the ocean includes a wide range of climatic and geographic regions that vary in their hydrologic, geologic, geomorphologic and oceanographic characteristics ${ }^{28}$. The geographic area covered in this study included small deltas, tidal systems and large rivers, which constituted 28 systems along a $17.2^{\circ}$ latitudinal band $\left(-0.6^{\circ} ;-47.6^{\circ}\right.$ to $\left.-17.75^{\circ} ;-39.2^{\circ}\right)$, representing $42 \%(3,875 \mathrm{~km})$ of the total length of the Brazilian coast $(9,198 \mathrm{~km})$. In the northern region, three systems (covering a total area of $2,870 \mathrm{~km}^{2}$ ) were studied, whereas in the northeastern region, 25 systems (covering a total area of $1,351.5 \mathrm{~km}^{2}$ ) were studied. The population density in the basins adjacent to these systems were $<100$ inhabitants $/ \mathrm{km}^{2}$ for 12 systems, $100 \leq$ inhabitants $/ \mathrm{km}^{2}<1,000$ for 13 systems and $>1,000$ inhabitants $/ \mathrm{km}^{2}$ for 3 systems (Table 1).

According to the Köppen climate classification system ${ }^{29}, 7$ of the systems are classified as climate type $A m$ (tropical wet climate), 6 systems as type $A f$ (tropical rainforest climate), 11 systems as $A w$ (tropical wet and dry or savanna climate) and 4 systems as BSh (semi-arid climate). According to this classification system, tropical climates and dry (arid and semi-arid) climates are present in our study area (Fig. 1).

According to an estuarine gradient classification system ${ }^{30}, 8$ of the systems are characterized as tidal fresh and upper estuary type, 11 belongs to the inner estuary type, 3 to the middle estuary type and 6 to the lower estuary type (Table 1).

River discharge data were obtained from the database of the Brazilian National Water Agency ${ }^{31}$, and demographic data were obtained from a database of the Brazilian Institute of Geography and Statistics ${ }^{32}$.

Sampling, analysis and calculation methods. In situ measurements were conducted from a boat during 12 continuous months (July 2012-June 2013) in estuarine portions $(0.5 \leq$ salinity $<35)$ of the 6 systems of the coast of the state of Pernambuco $\left(-7.55^{\circ} ;-34.8^{\circ}\right.$ to $\left.-8.85^{\circ} ;-35.1^{\circ}\right)$. Temperature and salinity (conductivity) were measured using a CTD (Sea Bird Electronics SBE911plus ${ }^{\circledR}$ - Washington, USA). Measured salinity was verified via comparison with the chlorinity, which was determined using $\mathrm{AgNO}_{3}$ titration ${ }^{33} \cdot \mathrm{pH}$ was measured on the NBS scale on board and after sample collection using a $\mathrm{pH} /$ ion analyzer 350 and a Ross combination electrode (Orion ${ }^{\circledR}$ ). The precision and the accuracy of the $\mathrm{pH}$ measurements were \pm 0.005 units and $0.1 \%$, respectively. In the laboratory, total alkalinity (TA) was determined using analytical procedures described by the US Geological Survey (USGS) for water samples ('ANC-alkalinity and acid neutralizing capacity') using the inflection point titration method ${ }^{34}$. The precision and accuracy of TA determinations were $\pm 20 \mu \mathrm{mol} \mathrm{kg}^{-1}$ and 5\%, respectively. Dissolved inorganic nutrients (phosphate (DIP) and silicate) were analyzed according to Reference 33, after filtration of the samples using $0.47-\mathrm{mm}$ Whatman ${ }^{\circledR} \mathrm{GF} / \mathrm{C}$ glass fiber filters. The precision was $0.01 \mu \mathrm{mol}$ for DIP and $0.03 \mu \mathrm{mol}$ for silicate. The accuracy was $\pm 2 \%$ for DIP and $\pm 6 \%$ for silicate.

Additionally, we estimated the amount of carbon emissions from 22 estuaries on the Brazilian coast (several months between 2001 and 2012) using measurements of salinity, temperature, phosphate, silicate, dissolved oxygen (DO), alkalinity and $\mathrm{pH}$ together with data stored at a monthly resolution from monitoring records of sources linked to states and universities in Brazil. The relative oxygen saturation (DO\%) in the water was calculated from the DO concentrations and oxygen solubility in the water at the field temperature and salinity. The apparent oxygen utilization (AOU) was computed using oxygen solubility equations ${ }^{35}$. $p \mathrm{CO}_{2}, \mathrm{FCO}_{2}$ and DIC were computed using the salinity, temperature, nutrients (phosphate and silicate), $\mathrm{pH}$ and $\mathrm{TA}$ measurements with dissociation constants given for a salinity range of 0 to $50^{36}$ in the $\mathrm{CO}_{2} \mathrm{Calc}^{\circledR}$ program ${ }^{37}$. Daily and monthly wind speed and barometric pressure data were obtained from the Brazilian Meteorological Institute (INMET) for stations that were close to the respective estuaries. The molar fraction of atmospheric $\mathrm{CO}_{2}\left(\mathrm{XCO}_{2}\right)$ was obtained from NOAA (http://esrl.noaa.gov) $(\mathrm{ppm})$, and $\mathrm{pH}_{2} \mathrm{O}=$ water vapor pressure ( $\left.\mu \mathrm{atm}\right)$ was obtained from Reference 38 . The gas transfer rate was calculated using the equation given in Reference 39.

Statistical analyses (regression analyses, t-tests, Spearman's correlation, principal component analysis or PCA and descriptive statistics) were performed using the XLSTAT $^{\circledR} 2010$ software.

1. Borges, A. V. Do we have enough pieces of the jigsaw to integrate $\mathrm{CO}_{2}$ fluxes in the coastal ocean? Estuaries 28, 3-27 (2005).

2. Laruelle, G. G., Dürr, H. H., Slomp, C. P. \& Borges, A. V. Evaluation of sinks and sources of $\mathrm{CO}_{2}$ in the global coastal ocean using a spatially-explicit typology of estuaries and continental shelves. Geophys. Res. Lett. 37, L15607 (2010).

3. Cole, J. J. et al. Plumbing the Global Carbon Cycle: Integrating Inland Waters into the Terrestrial Carbon Budget. Ecosystems 10, 172-185 (2007).

4. Araujo, M., Noriega, C., Veleda, D. \& Lefèvre, N. Nutrient Input and $\mathrm{CO}_{2}$ Flux of a Tropical Coastal Fluvial System with High Population Density in the Northeast Region of Brazil. JWARP 05, 362-375 (2013).

5. Frankignoulle, M. et al. Carbon dioxide emission from european estuaries. Science 282, 434-6 (1998).

6. Chen, C.-T. A., Huang, T.-H., Fu, Y.-H., Bai, Y. \& He, X. Strong sources of $\mathrm{CO}_{2}$ in upper estuaries become sinks of $\mathrm{CO}_{2}$ in large river plumes. Curr. Opin. Environ. Sustainability 4, 179-185 (2012).

7. Abril, G. \& Borges, A. V. Carbon Dioxide and Methane Emissions from Estuaries. in Greenhouse Gas Emissions: Fluxes and Processes, Hydroelectrics Resevoirs and Natural Environments, (eds Tremblay, A., Varfalvy, L., Roehm, C. \& Garneau, M.), 187-207 (Springer-Verlag, Berlin, Germany, 2004).

8. Borges, A. V., Delille, B. \& Frankignoulle, M. Budgeting sinks and sources of CO 2 in the coastal ocean: Diversity of ecosystems counts. Geophys. Res. Lett. 32, 1-6 (2005).

9. Chen, C. T. \& Borges, A. Reconciling opposing views on carbon cycling in the coastal ocean: continental shelves as sinks and near-shore ecosystems as sources of atmospheric $\mathrm{CO}_{2}$. Deep Sea Res. Part II 6, 578-590 (2009).

10. Kempe, S. Sinks of the anthropogenically enhanced carbon cycle in surface fresh waters. J. Geophys. Res. Atmos. 89, 4657-4676 (1984).

11. Souza, M. F. L., Gomes, V. R., Freitas, S. S., Andrade, R. C. B. \& Knoppers, B. Net Ecosystem Metabolism and Nonconservative Fluxes of Organic Matter in a Tropical Mangrove Estuary, Piauí River (NE of Brazil). Estuaries Coasts 32, 111-122 (2009)

12. Noriega, C. E. D., Araujo, M. \& Lefèvre, N. Spatial and Temporal Variability of the $\mathrm{CO}_{2}$ Fluxes in a Tropical, Highly Urbanized Estuary. Estuaries Coasts 36, 1054-1072 (2013).

13. Souza, W. F. L. \& Knoppers, B. Fluxos de água e sedimentos a costa leste do Brasil: Relações entre a tipologia e as pressões antrópicas. Geochimica Brasiliensis 17, 57-74 (2003).

14. CONAMA-National Council of the environment. Determination CONAMA $\mathrm{N}^{\circ} 357$ <http://www.mma.gov.br/port/conama> (2005); Data of access: 18/10/ 2013.

15. Neal, C., House, W., Jarvie, H. \& Eatherall, A. The significance of dissolved carbon dioxide in major lowland rivers entering the North Sea. Sci. Total Environ. 210211, 187-203 (1998).

16. Abril, G., Etcheber, H., Borges, A. V. \& Frankignoulle, M. Excess atmospheric carbon dioxide transported by rivers into the Scheldt estuary. C. R. Acad. Sci. II A 330, 761-768 (2000)

17. Macêdo, S., Flores-Montes, M. \& Costa, K. M. Condições hidrológicas da Zona Econômica Exclusiva (ZEE) do Nordeste do Brasil. in Meteorologia e Sensoriamento Remoto, Oceanografia Física, Oceanografia Química e Oceanografia Geológica (Programa REVIZEE-SCORE Nordeste, V. 1), (Ed Hazin, F.), 104-136 (Editora Martins \& Cordeiro, Fortaleza, Brazil, 2009).

18. Silva, Alex Costa da, Araujo, M. \& Bourlès, B. Variação sazonal da estrutura de massas de água na plataforma continental do amazonas e área oceânica adjacente. Rev. Bras. Geof. 23, 145-157 (2005).

19. Leote, C., Ibánhez, J. S. \& Rocha, C. Submarine Groundwater Discharge as a nitrogen source to the Ria Formosa studied with seepage meters. Biogeochemistry 88, 185-194. doi:10.1007/s10533-008-9204-9 (2008).

20. Ibánhez, J. S. P., Leote, C. \& Rocha, C. Porewater nitrate profiles in sandy sediments hosting submarine groundwater discharge described by an advectiondispersion-reaction model. Biogeochemistry 103, 159-180. doi:10.1007/s10533010-9454-1 (2010).

21. Cai, W.-J. Estuarine and Coastal Ocean Carbon Paradox: CO 2 Sinks or Sites of Terrestrial Carbon Incineration? Ann. Rev. Mar. Sci. 3, 123-145. doi:10.1146/ annurev-marine-120709-142723 (2011).

22. Mortatti, J. et al. Origem do Carbono Inorgânico Dissolvido no Rio Tietê (São Paulo): reações de equilíbrio e variabilidade temporal. Geochim. Bras. 20, 267-277 (2006).

23. Huang, T.-H., Fu, Y.-H., Pan, P.-Y. \& Chen, C.-T. A. Fluvial carbon fluxes in tropical rivers. Curr. Opin. Environ. Sustainability 4, 162-169 (2012). 
24. Sarma, V. V. S. S. et al. Carbon dioxide emissions from Indian monsoonal estuaries. Geophys. Res. Lett. 39, L03602 (2012).

25. Laruelle, G. G. et al. Global multi-scale segmentation of continental and coastal waters from the watersheds to the continental margins. Hydrol. Earth. Syst. Sc. 17, 2029-2051 (2013)

26. Chen, C.-T. A. et al. Air-sea exchanges of $\mathrm{CO}_{2}$ in the world's coastal seas. Biogeosciences 10, 6509-6544 (2013).

27. Gazeau, F., Smith, S. V., Gentili, B., Frankignoulle, M. \& Gattuso, J.-P. The European coastal zone: characterization and first assessment of ecosystem metabolism. Estuar. Coast. Shelf S. 60, 673-694 (2004).

28. Dominguez, J. M. L. The Coastal Zone of Brazil: an Overview. J. Coastal Res. SI39, 16-20 (2004).

29. Peel, M. C., Finlayson, B. L. \& Mcmahon, T. A. Updated world map of the Köppen-Geiger climate classification. Hydrol. Earth. Syst. Sc. 11, 1633-1644 (2007).

30. McLusky, D. S. Marine and estuarine gradients - An overview. Neth. J. Aquat. Ecol. 27, 489-493 (1993)

31. ANA-Brazilian National Water Agency < http://www.ana.gov.br> (2012); Date of access: 10/10/2013.

32. IBGE-Brazilian Institute of Geography and Statistics < http://www.ibge.gov.br > (2012): Date of access: 15/10/2013.

33. Grasshoff, K., Ehrhardt, M. \& K. K. Methods of seawater analysis. 419 (WileyVerlag, Weinheim, Germany, 1983).

34. Rounds, S. A. Alkalinity and Acid Neutralizing Capacity. U.S., in Geological Survey Techniques of Water-Resources Investigations Book 9, Chap. A6, (eds U.S. Geological Survey), 1-45 (available online at $<$ http://pubs.water.usgs.gov/ twri9A $>$, 2012, data of access: 01/10/2013).

35. Garcia, F. H. \& I, I. G. Oxygen solubility in seawater: better fitting equations. Limnol. Oceanogr. 37, 1307-1312 (1992).

36. Millero, F. J., Graham, T. B., Huang, F., Bustos-Serrano, H. \& Pierrot, D. Dissociation constants of carbonic acid in seawater as a function of salinity and temperature. Mar. Chem. 100, 80-94 (2006).

37. Robbins, L., Hansen, M., Kleypas, J. \& meylan, S. CO2calc: A User-Friendly Seawater Carbon Calculator for Windows, Mac OS X, and iOS (iPhone). 17 (available online at $<$ http://pubs.usgs.gov/of/2010/1280>, 2010, data of access: 05/10/2013).

38. Weiss, R. F. \& Price, B. A. Nitrous oxide solubility in water and seawater. Mar. Chem. 8, 347-359 (1980).

39. Raymond, P. \& Cole, J. Gas Exchange in Rivers and Estuaries: Choosing a Gas Transfer Velocity. Estuaries 24, 312-317 (2001).

\section{Acknowledgments}

We thank the Brazilian National Institute of Meteorology (INMET) for the database used in this study. This work was supported by the National Institute of Science and Technology in Tropical Marine Environments, INCT-AmbTropic (CNPq/FAPESB Grants: 565054/ 2010-4 and 8936/2011).

\section{Author contributions}

Both authors (C.N. and M.A.) reviewed the manuscript.

\section{Additional information}

Supplementary information accompanies this paper at http://www.nature.com/ scientificreports

Competing financial interests: The authors declare no competing financial interests.

How to cite this article: Noriega, C. \& Araujo, M. Carbon dioxide emissions from estuaries of northern and northeastern Brazil. Sci. Rep. 4, 6164; DOI:10.1038/srep06164 (2014).

This work is licensed under a Creative Commons Attribution-NonCommercialNoDerivs 4.0 International License. The images or other third party material in this article are included in the article's Creative Commons license, unless indicated otherwise in the credit line; if the material is not included under the Creative Commons license, users will need to obtain permission from the license holder in order to reproduce the material. To view a copy of this license, visit http:// creativecommons.org/licenses/by-nc-nd/4.0/ 